\title{
PERMASALAHAN DAN SOLUSI PENGEMBANGAN PERBANKAN SYARIAH DI KOTA MADIUN
}

\author{
Ana Dhaoud Daroin ${ }^{1)}$, Aprilia Putri Ningtias ${ }^{2)}$ \\ Universitas PGRI Madiun \\ anadha@unipma.ac.id
}

\begin{abstract}
Islamic banks implement a new concept that is not the same as the concept that has been known and embraced by conventional banking. The rapid development of banking today is not matched by an increase in the quality of its services. Many banks are only concerned with services in certain aspects by ignoring other aspects of service. The objectives in this study are (1) to identify the problems faced; (2) identify development efforts made by Islamic banks in Madiun. This research is a qualitative research with a phenomenological approach, by the descriptive method. Data processing techniques and checking the validity of the data is done by data triangulation techniques. Triangulation of data used in this study is the triangulation of methods and triangulation of theory. The results of the research findings state that the problems faced by Islamic banks in the city of Madiun in terms of HR and products. Problems in terms of HR include work motivation of employees, the level of public trust in Islamic banks is still low and the wrong mindset about Islamic banking. The problem in terms of products is the existence of miss perception of the contract between the customer and the bank. Development solutions carried out by banks through employee trainees and certification programs then conduct certification evaluations. In terms of products promoting the \#ayohijrah program, and cooperating with basic Islam. In terms of services, there is a prizes savings program and ball pick-up strategy
\end{abstract}

Keywords: Islamic Banks, Conventional Banks, Development Of Islamic Banks, Banking Management

\begin{abstract}
Abstrak
Bank syariah mengimplementasikan suatu konsep baru yang tidak sama dengan konsep yang selama ini dikenal serta dianut oleh perbankan konvensional. Pesatnya perkembangan perbankan saat ini tidak diimbangi dengan peningkatan kualitas pelayanananya. Banyak perbankan yang hanya mementingkan pelayanan pada aspek-aspek tertentu dengan mengindahkan aspek pelayanan yang lain tujuan dalam penelitian ini adalah (1) mengidentifikasi permasalahan yang dihadapi; (2) mengidentifikasi upaya pengembangan yang dilakukan oleh bank syariah di Madiun. Penelitian ini adalah penelitian kualitatif dengan pendekatan fenomologi , dengan metode deskirptif. Teknik pengolahan data dan pengecekan keabsahan data dilakukan dengan teknik triangulasi data. Trianggulasi data yang digunakan dalam penelitian ini adalah trianggulasi metode dan trianggulasi teori.Hasil temuan penelitian menyatakan bahwa masalah yang dihadapi oleh bank syariah di kota Madiun dari segi SDM dan produk. Masalah dari segi SDM meliputi motivasi kerja karyawan, tingkat kepercayaan masyarakat kepada bank syariah yang masih rendah dan pola pikir yang keliru mengenai perbankan syariah. Masalah dalam hal produk adalah adanya miss persepsi akad antara nasabah dengan pihak bank. Solusi pengembangan yang dilakukan oleh bank melalui trainee karyawan dan program sertifikasi kemudian melakukan evaluasi sertifikasi. Dari segi produk menggalakkan program \#ayohijrah, serta melakukan kerjasama dengan basic islam. Dari segi layanan melakukan program tabungan berhadiah dan strategi jemput bola.
\end{abstract}

Kata kunci: Bank Syariah, Bank Konvensional, Pengembangan Bank Syariah, Manajemen Perbankan 


\section{PENDAHULUAN}

Kebutuhan masyarakat akan bank menjadi tuntutan pada 1 dekade terakhir. Hasil survei Institut Pertanian Bogor (2004) menunjukkan bahwa $94,5 \%$ responden setuju bahwa peranan perbankan dalam kehidupan sehari-hari sangat penting. Alasan yang mendasari argumen responden adalah aspek permodalan dan keuntungan yang didapat oleh masyarakat. Berdasarkan data dari badan pusat statistik jumlah lembaga keuangan bank, baik bank persero, bank pemerintah daerah, bank swasta nasional, bank umum syariah maupun bank asing dan campuran konvensional pada tahun 2010 sejumlah 122 bank. Jumlah ini meningkat drastis, dimana pada tahun 2018 jumlahnya menjadi 282 bank. Hal ini membuktikan animo masyarakat yang tinggi akan kebutuhan pada transaksi lembaga keuangan bank. Kemajuan jaman agar transaksi keuangan berjalan cepat, efisien dan aman menjadi faktor pemicu tingginya minat masyarakat akan bank. Kampanye pemerintah melalui program "Ayo ke Bank" di dukung kesadaran masyarakat Indonesia akan bank menjadikan jumlah unit usaha bank yang kian merembah hingga ke pelosok desa.

Sejarah mencatat, terpuruknya ekonomi Indonesia pada tahun 1998 ketika terjadi krisis moneter, melemahkan setidaknya tiga sektor sentral, yaitu sektor perbankan, manufaktur dan konstruksi. Terpuruknya sektor perbankan karena tingginya suku bunga pinjaman. Fenomena bangkrutnya bank konvensional ini tidak berlaku bagi pelaku usaha yang menggunakan dana dari bank syariah. Para pengusaha yang mengguna-kan jasa di bank syariah tidak perlu membayar bunga hingga puluhan persen karena bank syariah menggunakan sistem bagi hasil, bukan bunga. Fenomena inilah yang akhirnya menjadikan bank syariah menjadi sorotan bagi masyarakat yang ingin terhindar dari bunga yang sejatinya merugikan (Syauqoti, 2018:16).

Kejenuhan pada sistem bank konvensional juga didasari dengan sistem ribawi dalam bentuk bunga bank. Dimana dalam ajaran Islam, yang dianut sebagian besar penduduk Indonesia, tertulis bahwa bunga bank termasuk riba yang hukumnya haram. Landasan tersebut, tertuang dalam A1 Quran surat Al-Baqarah ayat 278-279.

"Hai orang-orang yang beriman, bertakwalah kepada Allah dan tinggalkan sisa riba (yang belum dipungut) jika kamu orang-orangyang beriman(278)

Maka jika kamu tidak mengerjakan (meninggalkan sisa riba), maka ketahuilah, bahwa Allah dan Rasul-Nya akan memerangimu. Dan jika kamu bertaubat (dari pengambilan riba), maka bagimu pokok hartamu; kamu tidak menganiaya dan tidak (pula) dianiaya (279)."

Masyarakat saat ini lebih berhati-hati dalam mengambil pinjaman/kredit dari bank. Sistem bunga yang dianggap membebani masyarakat, maraknya gerakan hijrah dan kajian Islam di sosial media yang tidak terbatas dan diakses oleh masyarakat. Merupakan faktor pendorong besarnya keinginan masyarakat akan sistem kredit baru yang lebih baik dan ramah.

Adanya dorongan yang kuat dari berbagai elemen masyarakat yang menghendaki adanya lembaga keuangan atau sistem perbankan alternatif yang dapat menyediakan layanan fasilitas keuangan dan perbankan yang sesuai dengan prinsip-prinsip syariah serta keyakinan agama, merupakan salah satu faktor pendorong utama lahirnya perbankan syariah di tanah air ini (Bank Indonesia, 2002).

Karena pada dasarnya bank syariah mengimplementasikan suatu konsep baru yang tidak sama dengan konsep yang selama ini dikenal serta di anut oleh perbankan konvensional. Bahkan produk yang merupakan bisnis utama, pencetak pendapatan 
terbesar bagi sebuah bank konvensional seperti fasilitas kredit dengan sistem bunga yang melekat pada bank konvensional, justru merupakan hal yang amat dilarang atau diharamkan dalam bank Islam. (Sawarjuwono, 2005:71). Sistem bunga Bank konvensional dalam praktik pemberian kredit ke masyarakat menggunakan sliding rate, Flat rate, floating rate, discount rate dan add-on. Dalam ekonomi syariah, kelima sistem bunga tersebut tidak diperbolehkan, karena dihukumkan riba.

Di Indonesia kehadiran perbankan syariah sekitar tahun 1992. Bank syariah yang pertama berdiri adalah Bank Muamalat Indonesia, yang merupakan hasil prakarsa dari Majelis Ulama Indonesia, pemerintah dan Ikatan Cendekiawan Muslim Indonesia (ICMI). Ketika Indonesia mengalami krisis moneter tahun 1998, Bank Syariah ikut terpuruk hingga harus mendapatkan suntikan dana dari International Development Bank (IDP) pada tahun 1999-2002.

Sebagai negara dengan jumlah penduduk muslim terbesar di dunia, industri perbankan syariah di Indonesia mempunyai peluang yang besar untuk tumbuh dan berkembang. Seiring dengan berjalannya waktu, keberadaan perbankan syariah mulai diperhitungkan di industri perbankan. Perkembangan perbankan syariah di Indonesia tak lepas dari peran pemerintah dalam hal regulasi perbankan yang diatur dalam Undang-Undang no 10 tahun 1998 dimana bank konvensional diperkenankan mempunyai unit usaha syariah. Regulasi ini disebut "dual banking system".

Sejalan dengan regulasi tersebut bermunculan bank konvensional yang juga membuka unit usaha syariah, seperti BRI Syariah, BNI Syariah, Bank Mega Syariah, BCA Syariah, BTN Syariah, Bank Syariah Mandiri, Bukopin Syariah.

Dalam industri jasa, kepuasan konsumen merupakan hal yang menjadi poin penting. Standar pelayanan yang ramah dan proesional akan membuat konsumen merasa nyaman dan dihargai. Kualitas pelayanan yang baik berbanding lurus dengan tingginya angka kepuasan konsumen pada produk jasa. Begitu pula dengan jasa perbankan, konsumen atau nasabah perbankan akan loyal dan merasa nyaman untuk melakukan transaksi dengan bank tersebut.

Secara empiris terdapat banyak kritik tentang kualitas pelayanan di bank syariah. Mulai dari penerapan sistem bagi hasil, keraguan kesesuaian operasional bank syariah dengan syariah islam, dan keluhan pelayanan frontoffice seakan kurang profesional. (Astuti, Wilasari, \& Utami, 2012). Pesatnya perkembangan perbankan saat ini tidak diimbangi dengan peningkatan kualitas pelayanananya. Banyak perbankan yang hanya mementingkan pelayanan pada aspek-aspek tertentu dengan mengindahkan aspek pelayanan yang lain. (Marimin \& Musthofa, 2018). Tempat duduk yang terbatas dan kurang memadai, antrian panjang adalah beberapa contohnya (Marimin \& Musthofa, 2018). Perbankan syariah seharusnya memberikan pelayanan yang lebih berkualitas dibandingkan pesaingnya untuk menciptakan kepuasan nasabah.

Sejalan dengan pendapat diatas, Arshad, Yusoff \&Tahir (2016: 223) menyatakan bahwa Traditional models are verified over decades. In contrast, islamic finance models need to be studies further to overcome all the recent challenges of the economic world. Therefore, Shari'ah scholars, having expertise in economics and finance should come forward for formulating new strategies and products in line with prerequisites of today's environment. New regulation should be developed to make the financial and governance system more efficient. Arshad, Yusoff \& Tahir menghimbau para ahli sarjana syariah untuk merumuskan strategi dan produk baru agar sistem 
keuangan perbankan syariah lebih efisien.

Berbagai masalah yang dihadapi oleh perbankan syariah, jika mampu diatasi akan memberikan manfaat yang besar bagi para nasabah, praktisi perbankan syariah dan pemerintah. Peningkatan kualitas layanan, peningkatan sumber daya manusia bank syariah, product knowledge perbankan syariah menjadi bagian yang penting untuk dikembangkan dalam menambah kepercayaan masyarakat pada bank syariah. Mencermati uraian tersebut, maka perlu dilakukan penelitian agar dapat mendeskripsikan secara detail masalah-masalah yang menyertai perkembangan perbankan syariah di kota Madiun.

Penelitian dilakukan untuk mencari solusi upaya pengembangan demi peningkatan kualitas perbankan syariah. Penelitian dilakukan dari prespektif sumber daya manusia, produk perbankan syariah, serta etika dan layanan bank syariah, karena setelah dicermati masalah pokok yang harus segera diselesaikan pada perbankan syariah adalah masalah pada produk, layanan dan sumber daya manusia. Peneliti ingin menggali lebih dalam tentang Permasalahan dan upaya pengembangan yang dilakukan oleh Bank Muamalat Indonesia kantor cabang Madiun.

Sejarah terbentuknya Bank syariah di Indonesia dimulai tahun 90an. Menurut Kasmir (2015:165) kehadiran bank yang berdasarkan syariah di Indonesia masih relatif baru, pada awal tahun 1990-an. Terbentuknya UU No 19 tahun 2008 tentang surat Berharga Syariah Negara (SBSN) dan UU no 21 tahun 2008 tentang perbankan syariah adalah wujud peran serta pemerintah dan masyarakat. Menurut (Ghofur: 128) Prinsip utama yang dijadikan landasan dalam operasional lembaga keuangan syariah antara lain (1). Bebas dari unsur maisir, gharar, dan riba; (2) Menjalankan bisnis dan aktivitas perdagangan yang berbasis pada perolehan yang sah menurut syariah Islam.

Lebih lanjut (Ghofur, 2017:136) menerangkan bahwa ciri lembaga keuangan syariah meliputi:

1. Dalam menerima titipan dan investasi, lembaga keuangan syariah harus sesuai dengan fatwa dewan pengawas syariah.

2. Hubungan antara investor (penyimpan dana), pengguna dana dan lembaga keuangan syariah sebagai intermediary institution, berdasarkan kemitraan, bukan hubungan debitur-kreditur.

3. Bisnis lembaga keuangan syariah bukan hanya berdasarkan profit oriented, tetapi juga falah oriented, yakni kemakmuran di dunia dan kebahagian di akhirat.

4. Konsep yang digunakan dalam transaksi lembaga syariah berdasarkan prinsip kemitraan bagi hasil, jual beli atau sewa menyewa guna transaksi komersial, dan pinjam-meminjam (qardh/kredit) guna transaksi sosial.

5. Lembaga Keuangan Syariah hanya melakukan investasi yang halal dan tidak menimbulkan kemudharatan serta tidak merugikan syiar islam.

Sejalan dengan pendapat Ghofur, Yusuf (2015:243) mengemukakan bahwa islamic banking can be defined as a bank that operated on profit sharing system that gives an advantage either for the society or the banks. The islamic banking offers the justice in transaction, the ethical investment and proposes the cooperative values and brotherhood in production, and avoids the speculative activities.

Berdasarkan dua pendapat di atas, dapat disimpulkan bahwa salah satu perbedaan mendasar antara bank konvensional dengan bank syariah terletak pada prinsip yang menjadi landasan akad atau kesepakatan saat transaksi dengan nasabah, dimana menghilangkan aktifitas spekulatif pada investasi. Menurut pendapat Hakim (2019:23-24) Prinsip bagi hasil bank syariah yang dijadikan 
landasan transaksi dalam produk perbankan syariah meliputi:

1. Prinsip titipan

Prinsip wadi'ah dikenal dalam prinsip titipan yaitu perjanjian antara pemilik barang dimana pihak penyimpan bersedia menyimpan dan menjaga keselamatan barang yang dititipkan kepadanya. Dalam perbankan syariah prinsip ini dikembangkan dalam produk simpanan, yaitu giro al-wadi'ah dan tabungan al-wadiah.

2. Prinsip bagi hasil

a) Al-musyarakah yaitu perjanjian kerjasama antara dua pihak atau lebih pemilik modal untuk membiayai biaya usaha.

b) Al-mudharabah yaitu perjanjian antara pemilik modal dengan pengusaha (dalam perjanjian ini, pemilik modal bersedia membiayai sepenuhnya suatu proyek atau usaha dan pengusaha setuju untuk mengelola proyek tersebut dengan pembagian hasil sesuai dengan perjanjian.

c) Al-Muzara'ah yaitu praktik memberikan lahan pertanian kepada si penggarap untuk ditanami dan dipelihara dengan imbalan tertentu dari hasil panen.

3. Prinsip pengambilan keuntungan

Atau jual beli yaitu proses pemindahan hak milik barang atau aset dengan menggunakan uang sebagai media. Jenisjenis jual beli adalah:

a) Al musyawamah adalah praktik jual beli dimana penjual memasang harga tanpa memberi tahu si pembeli tentang berapa margin keuntungan yang diambilnya.

b) At tuliah adalah menjual dengan harga beli tanpa mengambil keuntungan sedikitpun, seolah si penjual menjadikan pembeli sebagai walinya (tauliah) atas barang atau aset. c) Al Murabahah yaitu menjual dengan harga asal ditambah margin keuntungan yang telah disepakati.

d) Al-Muwadhaah yaitu menjual dengan harga lebih rendah dari harga beli dengan kata lain, Al Muwadhaah merupakan bentuk kebalikan dari al Murabahah.

e) Al-Muqayadhah merupakan bentuk transaksi awal dimana barang ditukar dengan barang/barter.

f) Al-Mutlaq yaitu bentuk jual beli biasa dimana barang ditukar dengan uang.

g) Ash-Sharfjual beli valuta asing dimana uanh ditukar dengan uang.

h) Bay' As-Sallam yaitu proses jual beli dimana pembayaran dilakukan dimuka manakala penyerahan barang dilakukan kemudian.

i) Bay' bitsaman Ajili yaitu menjual dengan harga asal ditambah margin keuntungan yang telah disepakati dan dibayar secara kredit.

j) Bay' Al-Istishna yaitu kontrak pemesanan yang ditandatangani bersama antara pemesan dan produsen untuk pembuatan suatu jenis barang tertentu.

4. Prinsip sewa (Al-Ijarah) yaitu perjanjian antara pemilik barang dengan penyewa yang memperbolehkan penyewa memanfaatkan barang tersebut dengan membayar sewa sesuai dengan perjanjian kedua belah pihak. Setelah masa sewa berakhir, barang akan dikembalikan kepada pemilik.

5. Prinsip pengambilan fee dimana prinsip ini dijadikan dasar pengembangan produk jasa layanan (service)

a) Al-Kafalah adalah suatu jaminan yang diberikan oleh penanggung kepada pihak ketiga untuk memenuhi kewajiban pihak kedua yang ditanggungnya.

b) Al-Wakalah adalah perjanjian pemberian kuasa kepada pihak lain 
yang ditunjuk untuk mewakilinya dalam melaksanakan tugas atas nama pemberi kuasa.

c) Al-Hiwalah adalah pengalihan kewajiban dari suatu pihak yang mempunyai kewajiban kepada pihak lain.

d) Al-Fialah adalah suatu kontrak dimana pihak pertama menjanjikan imbalan tertentu kepada pihak kedua atas pelaksanaan usaha atau tugas

6. Prinsip biaya administrasi (Al-Qardul Hasan/benevolent loan) yakni perjanjian pinjam-meminjan uang atau barang dengan tujuan untuk membantu penerima pinjaman. Penerima pinjaman wajib mengembalikan utangnya dalam jumlah yang sama dan apabila peminjam tidak mampu mengembalikan pada waktunya, peminjam tidak boleh dikenakan sanksi. Atas kerelaanya, peminjam diperbolehkan memberikan imbalan kepada pemilik barang/uang.

Prinsip-prinsip perbankan syariah tersebut diaplikasikan dalam produk perbankan syariah. Sesuai dengan fungsi perbankan untuk menghimpun dana dari masyarakat kemudian menyalurkan kembali kepada masyarakat, maka produk perbankan syariah secara umum diklasifikasikan menjadi tiga kelompok yaitu:

1. Produk penghimpunan dana

Didasarkan pada firman Allah surat AnNisa ayat 58

"Sesungguhnya Allah menyuruh kamu menyampaikan amanat kepada yang berhakmenerimanya...."

Pengimpunan dana dalam bentuk simpanan berupa deposito, giro dan tabungan. Akad yang biasanya digunakan adalah prinsip wadiah dan mudharabah.

2. Produk penyaluran dana

Penyaluran dana dalam bank syariah menggunakan 3 prinsip yaitu prinsip jual beli (Ba'i) baik Murabahah, Salam dan Istishna; sistem sewa (ijarah) dan sistem bagi hasil (syirkah) yang dibagi menjadi dua macam produk yaitu Musyarakah dan Mudharabah.

3. Produk Jasa

a) Sharf

Disebut juga jual beli valuta asing berbeda yang penyerahannya harus dilakukan pada waktu yang sama sesuai dengan kurs pada saat itu juga. Bank akan mengambil keuntungan untuk jasa tersebut.

b) Wakalah (amanat)

Penyerahan mandat atau amanat dari nasabah kepada perbankan syariah untuk melaksanakan suatu permintaan tergantung keinginan pemberi kuasa. Permintaan tersebut misalnya transfer atau penagihan utang.

c) Hawalah

Pengalihan utang dari pemilik utang kepada pihak lain yang akan menanggungnya. Praktiknya seperti pemberian modal kepada supplier agar mendapat biaya usaha. Bank akan mendapat upah atas pemindahan utang tersebut.

d) Kafalah

Merupakan jasa penjaminan yang ditawarkan pihak bank, dimana bank sebagai penjamin dan nasabah sebagai pihak yang dijamin. Tujuanya untuk menjamin pembayaran suatu kewajiban.

e) Rahn (Gadai)

Secara sederhana seperti sistem gadai, nasabah menyerahkan suatu barang yang memenuhi kriteria sebagai jaminan yang diserahkan kepada pihak bank untuk kemudian bank memberikan pinjaman.

Sumber daya manusia (SDM) merupakan manajemen kunci tercapainya target dalam industri jasa perbankan. SDM dituntut untuk mengerti ilmu ekonomi, ilmu 
perbankan dan ilmu syariah itu sendiri. SDM yang berkualitas mampu mengembangkan suatu perusahaan. Sehingga dapat dikatakan bahwa SDM merupakan aset sekaligus kunci yang paling dominan dalam mengelola industri perbankan syariah.

Optimalisasi hasil pencapaian perusahaan akan sangat didukung oleh peningkatan peran direksi dan manager yang terlibat dalam pengelolaan SDM dan pra staff yang mampu bekerja dengan sebaik-baiknya. Perubahan lingkungan bisnis yang begitu cepat menuntut pengelolaan SDM secara terpadu antara pemahaman sistem dan manusia yang ditunjang oleh keahlian, ketrampilan, kepemimpinan, dan kerjasama kedua belah pihak (Farizal, 2010: 53-54).

Berbicara tentang keunggulan SDM pada perbankan syariah tidak bisa dilepaskan dari empat dimensi kompetensi yaitu mindset (cara berpikir), kompetensi (pengetahuan, keahlian dan kemampuan), karakter (sidiq, amanah, fathonah, dan tabligh) dan kualitas motivasi kerja pada bank syariah (jati diri sebagai faktor motivasi). Pemikiran tentang keunggulan SDM dengan karakter seperti itu, dalam manajemen perbankan syariah adalah meletakkan peran orang dalam organisasi untuk selalu melakukan peningkatan kualitas dan inovasi baik terhadap proses, sistem maupun produk dan pelayanan. Sehingga dapat meningkatkan kualitas kontribusi semua orang dalam organisasi berbasis nilainilai syariah. Menjadi tugas semua pimpinan mempersiapkan, mengelola dan mempertahankan SDM yang memiliki kemampuan dan komitmen tinggi terhadap visi, misi value dan tujuan perbankan syariah (Alwi, 2013:164).

Sejalan dengan pendapat Alwi, Hadjri, et al (2019: 126) dalam hasil penelitiannya menyatakan bahwa All Islamic Human Resources Management (IHRM) variables of islamic recruitment and selection, islamic training and islamic compensation had positive and significant effect on organizational commitment. Islamic recruitment and selection variable had the greatest influence on organizational commitment, following by islamic training variable and islamic compensation.

Lebih lanjut Hadjri et al menyatakan bahwa All variables IHRM namely Islamic recruitment and selection, islamic training and islamic compensation had a positive and significant effect on employee performance.

Dua pendapat tersebut, terlihat berbeda sudut pandang, namun bila kita cermati memiliki substansi yang hampir sama. Pendapat Alwi menitikberatkan pada mindset, kompetensi, karakter dan motivasi kerja, sedangkan pendapat Hadjri et all berfokus pada pemilihan SDM yang telah sesuai dengan karakteristik islam, kemudian dikembangkan dengan training islami, ditambah lagi dengan kompensasi/reward yang sesuai. Langkah ini terbukti secara positif berpengaruh terhadap pembentukan mindset, kompetensi, karakter dan motivasi kerja karyawan sehingga berdampak positif pula terhadap perusahaan.

Islamic finance, which is based on ethnics and islamic law of transactions, is part of this movement while putting the real economy at the heart of system. To compete with conventional finance, islamic finance faces challenges comparable to that of conventional finance performance (Nadia et al, 2014:107).

Tantangan yang dihadapai bank syariah agar bisa bersaing dengan bank konvensional salah satunya pada sisi pelayanan. Etika pelayanan bank syariah merupakan pelayanan prima yang dilakukan oleh pegawai perbankan syariah kepada nasabah dan calon nasabah. Dalam melakukan standar pengukuran service excellent jasa perbankan umum digunakan model CARTER dan SERVEQUAL.

Model SERVQUAL yang didasarkan pada perbedaan antara harapan dan persepsi 
pelanggan. Model SERVQUAL ini memiliki lima dimensi pengukuran kualitas pelayanan yang sampai saat ini secara umum telah banyak digunakan pada perusahaan jasa. Kelima dimensi itu adalah Reliability, Empathy, Tangible, Assurance, Responsiveness. Sifatnya yang umum untuk untuk mengukur kualitas pelayanan perusahaan jasa membuat perlunya penyesuaian jika diaplikasikan pada perusahaan yang berkarakter khusus seperti perbankan syariah (Putra \& Herianingrum, 2015).

Sejalan dengan pendapat Putra dan Herianingrum, Othman \& Owen dalam (Khaliq 2019:180) mengemukakan bahwa CARTER model adalah salah satu alternatif penyempurnaan SERVQUAL untuk mengukur kualitas pelayanan perbankan syariah. CARTER adalah instrumen yang dapat digunakan untuk mendefinisikan dan mengukur kualitas layanan perbankan syariah dan untuk membuat alat penilaian kualitas yang berguna, model ini memiliki enam sebagai berikut:

a. Compliance yang berarti kemampuan untuk memenuhi hukum Islam dan beroperasi berdasarkan prinsip perbankan dan ekonomi Islam.

b. Assurance adalah pengetahuan dan kesopanan karyawan dan kemampuan mereka untuk menyampaikan kepercayaan dan kepercayaan diri. Ini juga mencakup komunikasi verbal dan tertulis antara staf bank dan pelanggan

c. Reliability untuk melakukan layanan yang dijanjikan, ketergantungan dan akurasi.

d. Tangibles yang berarti penampilan fasilitas fisik, peralatan, personel, dan alat komunikasi

e. Emphaty adalah perhatian individual yang disediakan bank syariah untuk para pelanggannya

f. Responsiveness adalah kesediaan untuk membantu pelanggan dan memberikan layanan yang cepat.
Hasil penelitian yang dilakukan pada beberapa bank syariah di Tunisia, salah satunya Bank Zaytuna menunjukkan bahwa:

The constantly expanding research work carried on islamic banking and results confirming the superiority of the performance of the latter than conventional banks led us to find a relationship of this performance with the main purpose of islamic banking which is to offer products that meet islamic law and to promote fair and equitable transactions. From this, we added a religious ethic dimension measuring the true performance for an Islamic bank (Nadia et al,2014:120).

Berdasarkan penelitian Nadia et al tersebut, bank syariah di Tunisia lebih unggul secara performa dibandingkan dengan bank konvensional. Hal ini membuktikan bahwa bank syariah mampu bersaing di industri jasa perbankan. Bank syariah memiliki potensi yang besar untuk dikembangkan. Di Indonesia, bank syariah memang masih tergolong baru, namun memiliki potensi yang sama besarnya dengan bank syariah di negara lain. Bank syariah di Indonesia perlu dikembangkan baik dari segi layanan maupun produk dan sumber daya manusia.

Rusdiana (2016:237) mengemukakan bahwa 4 aspek permasalahan yang dihadapi oleh perbankan syariah di Indonesia yaitu (1) Belum memadainya permodalan bank syariah; (2) Lemahnya pemahaman praktisi bank syariah; (3) Kurangnya dukungan pemerintah; (4) Trust dan minat masyarakat terhadap bank syariah cenderung rendah. Sedangkan prioritas strategi kebijakan yang dianggap mampu menyelesaikan permasalahan industri perbankan syariah di Indonesia terdiri dari (1). Memperkuat permodalan dan skala usaha serta memperbaiki tingkat efisiensi; (2) Memperbaiki Kuantitas dan kualitas sumberdaya manusia bank syariah, berikut juga sistem informasi dan teknologi; (3) perbaikan struktur dana bank syariah dan harmonisasi pengaturan dan pengawasan. 
Sejalan dengan Rusdiana, menurut Subandi (2012:2) masalah utama perbankan syariah yaitu; aspek legalitas, aspek sumber daya manusia, dan aspek strategi pemasaran yang kurang inovatif. Beberapa strategi untuk menyelesaikan hal tersebut adalah; peningkatan kualitas layanan dan profesionalisme, inovasi produk yang lebih baik, sumber daya manusia yang berkualitas, dan seterusnya.

Kajian di atas semakin diperkuat dengan hasil penelitian Shidiqqi \& Rachmawati (2018:191) yang menyatakan bahwa Sharia Bank need to be more cautious in placing and distributing funds to Mudharib to ensure liquidity and improve profitability in Sharia Bank. In order to maintain their efficiency, sharia bank must focus in increasing the amount of financing that is provided for the productive sectors and should be able to supress or manage NPF value at a rational level. In addition, Sharia Bank also need to increase and expand the number of islamic financial products which can be districted into different segments and manage by numbers of branches in many regions in Indonesia.

Pada dasarnya bank syariah di Indonesia masih perlu dikembangkan, baik dari segi produk maupun layananan. Produk yang ada masih terbatas, sehingga belum memenuhi ekspektasi nasabah. Begitu pula dengan segi pelayanan yang masih dibawah standart layanan bank konvensional.

Berdasarkan Roadmap perbankan syariah Indonesia tahun 2015-2019 yang dikeluarkan oleh Otoritas Jasa Keuangan (OJK) menyebutkan bahwa masalah SDM di bank syariah masih akan selalu menghantui keberadaan bank syariah. Bank syariah masih kekurangan baik dari segi kuantitas dan kualitas SDM yang belum memadai serta teknologi informasi (TI) yang belum dapat mendukung pengembangan produk dan layanan.
SDM dan TI merupakan dua faktor uatama yang menentukan keberhasilan pengembangan produk dan layanan perbankan, serta operasional perbankan secara umum. Disadari bahwa kualitas SDM dan TI pada perbankan syariah secara umum masih di bawah kualitas perbankan konvensional. Tantangan kualitas dan kapasitas dalam SDM dan TI pada bank syariah yang mampu memahami dan mengiplementasikan prinsip-prinsip syariah. (OJK:2019).

Selain itu masalah SDM di bank syariah adalah karena komposisi di bank syariah tidak seimbang, $90 \%$ SDM di bank syariah tidak berlatar belakang pendidikan ekonomi syariah atau perbankan syariah. Pertumbuhan industri keuangan dan perbankan syariah rupanya belum diiringi dengan ketersediaan SDM di bidang tersebut. Ketua dewan pakar Ekonomi Syariah Indonesia Aries Mufti menyatakan meningkatnya kepercayaan masyarakat terhadap perbankan syariah berdampak pada tingginya pertumbuhan industri keuangan dan perbankan syariah. Pertumbuhan rataratanya sebesar 30-40 persen, jauh di atas rata-rata pertumbuhan bisnis keuangan dan perbankan konvensioal yang hanya tumbuh sekitar 10 persen.

Permasalahan pada perbankan syariah, di tanggapi berbeda oleh Bangsa (2015:288) menyatakan bahwa Indeed, the islamic banking industry has numerous challenges to overcome in order to secure its future growth, especialy with consumers from various segments becoming more demanding as they seek new and innovative products that could satisfy their needs. Menurut pendapat Bangsa, memiliki tantangan besar di masa depan, untuk merebut pangsa konsumen dari berbagai segmen melalui inovasi dan produk baru.

Berbagai masalah yang dihadapi oleh perbankan syariah, jika mampu diatasi akan memberikan manfaat yang besar bagi para 
praktisi perbankan syariah, pemerintah dan juga nasabah bank syariah. Peningkatan kualitas dan kuantitas sumber daya manusia, penguatan modal, dan inovasi strategi pemasaran menjadi bagian yang penting untuk dikembangkan dalam penguatan strategi pertumbuhan perbankan syariah.

Mencermati uraian tersebut, maka perlu dilakukan penelitian agar dapat mendeskripsikan secara detail masalah-masalah yang menyertai perkembangan perbankan syariah. Penelitian dilakukan untuk mencari solusi upaya pengembangan demi peningkatan pertumbuhan industri perbankan syariah. Penelitian dilakukan pada bank Muamalat Indonesia, Tbk . Alasan pemilihan lokasi penelitian di Bank Muamalat Indonesia, Tbk. merupakan bank syariah yang pertama berdiri, sehingga diharapkan telah memiliki banyak pengalaman tentang masalah dan upaya pengembangan perbankan syariah. Oleh karena itu penelitian tentang permasalahan dan solusi pengembangan perbankan syariah di kota Madiun dirasa perlu untuk dilakukan.

\section{METODE PENELITIAN}

\section{Tempat dan Waktu Penelitian}

Lokasi penelitian ini adalah PT. Bank Muamalat Indonesia, Tbk. Alasan pemilihan tempat penelitian tersebut karena PT. Bank Muamalat Indonesia, Tbk merupakan bank syariah yang pertama berdiri, sehingga diharapkan telah memiliki banyak pengalaman tentang masalah dan upaya pengembangan perbankan syariah. Waktu penelitian dilakukan selama bulan Februari.

\section{Jenis dan Metode Penelitian}

Jenis penelitian ini adalah penelitian kualitatif dengan pendekatan fenomenologi. Penelitian menekankan pada strategi inquiry untuk mencari makna, deskripsi baik yang bersifat alami maupun holistik, sehingga berdasarkan metodenya termasuk penelitian deskriptif. Sehingga dalam penelitian ini akan mendeskripsikan fenomena-fenomena baik alamiah maupun buatan manusia.

\section{Sumber Data dan Teknik Pengambilan Data}

Sumber data dalam penelitian ini adalah sumber data primer dan data sekunder. Sumber data primer merupakan data yang didapat dari informan penelitian dan relevan dengan tujuan penelitian. Data primer diperoleh dari wawancara dan observasi kepada informan. Data diperoleh dari pendapat dan pengalaman praktisi perbankan dalam mengatasi masalah dan mengembangkan perbankan syariah.

Sumber data sekunder merupakan data yang telah ada yang berkaitan dengan perbankan syariah dan masalahnya. Data sekunder diperoleh dari dokumen-dokumen yang relevan dengan topik penelitian. Teknik pengambilan data menggunakan nonprobabilitysampling.

\section{Teknik Pengumpulan Data}

Teknik Pengumpulan data dilakukan dengan observasi, indepth interview, analisis dokumen. Teknik pengolahan data dan pengecekan keabsahan data dilakukan dengan teknik triangulasi data. Trianggulasi data yang digunakan dalam penelitian ini adalah trianggulasi metode dan trianggulasi teori.

\section{Teknik Analisis Data}

Teknik analisis data yang digunakan dalam penelitian ini adalah teknik analisis interaktif, dimana data yang telah terkumpul kemudian direduksi,disajikan dan dibuat kesimpulan. Analisis data pada penelitian kualitatif pada dasarnya telah dimulai pada saat peneliti melakukan studi pendahuluan, tetapi secara umum analisis dimulai ketika peneliti menelaah data. 


\section{HASIL DAN PEMBAHASAN}

\section{Permasalahan yang dihadapi Bank Syariah Madiun}

a. SDM

1) Motivasi kerja karyawan

Permasalahan yang dihadapi bank syariah terkait sumber daya manusia adalah motivasi kerja karyawan. Karyawan adalah aset perusahaan. Karyawan yang memiliki motivasi kerja yang tinggi akan berpengaruh positif terhadap kinerja dan pencapaian target perusahaan. Begitu pula sebaliknya, karyawan yang memilki motivasi kerja rendah akan menghambat target perusahaan, lebih lanjut karyawan yang memiliki motivasi rendah dapat membawa iklim negatif bagi rekan kerja dan budaya perusahaan.

2) Tingkat kepercayaan masyarakat pada perbankan syariah yang masih rendah

Berdasarkan data dari Otoritas Jasa Keuangan (OJK:2019), market share bank syariah di tahun 2019 sebesar 6\%. Hal ini berarti 94\% market share perbankan Indonesia dikuasai bank konvensional. Data ini menunjukkan pada kita, masyarakat Indonesia masih "nyaman" bertransaksi dengan bank konvensional dibanding bank syariah.

3) Ada kecenderungan pola pikir masyarakat bahwa tidak ada perbedaan bank konvensional dengan perbankan syariah

Dalam bank konvensional dikenal sistem bunga bank, sementara dalam bank syariah bunga bank hukumnya haram karena mengandung riba. Dalam perbankan syariah sistem yang digunakan adalah sistem bagi hasil. Sebagian besar masyarakat menganggap sistem bagi hasil sama dengan bunga bank. Hal ini menjadi alasan utama, masyarakat "terlanjur nyaman" dan enggan beralih pada bank syariah, Alasan masyarakat lebih memilih bank konvensional dibanding bank syariah antara lain karena: a) Belum populernya akadakad perbankan syariah, b) jumlah kantor cabang dan ATM dan akses bank konvensional yang lebih mudah dijangkau nasabah.

b. Produk

Salah satu perbedaan mendasar bank konvensional dengan bank syariah adalah pada akad yang digunakan. Akad pada bank syariah melekat pada semua jenis produknya. Akad yang umum digunakan adalah al-mudharabah dan al-wadiah (titipan) Istilah dalam akad bank syariah masih baru dalam masyarakat Indonesia, begitu pula bagi masyarakat di Kabupaten Madiun. Hal ini terkadang menimbulkan permasalahan "miss persepsi" antara karyawan (Account Officer, Funding Officer dan Custumer Services) dengan nasabah tentang akad syariah dan penerapanya.

\section{Upaya pengembangan yang dilakukan oleh Bank Syariah Madiun}

a. Sumber Daya Manusia

1) Pengembangan karyawan melalui trainee dan sertifikasi

Upaya pengembangan yang dilakukan oleh bank syariah untuk meningkatkan kualitas SDMnya adalah memberikan kesempatan untuk mengupgrade pengetahuan perbankan, skill dan menambah motivasi kerja. Upaya tersebut dilakukan secara bergiliran dan terjadwal, sehingga tidak menganggu operasional perusahaan. Kesem- 
patan mengikuti trainee terbuka bagi semua karyawan sesuai dengan jenjang kepangkatan.

Kualifikasi umum rekrutmen Sumber daya Manusia pada bank syariah pada umumnya sama dengan bank konvensional. Hal yang membedakan adalah calon pegawai harus beragama islam, paham akan hukum islam dan berpakaian syari. Peningkatan skill dan pemahaman akan perbankan syariah. SDM bank syariah, sebagian besar bukan merupakan sarjana dibidang ilmu syariah/ perbankan syariah. Hal ini mengingat rumpun ilmu ekonomi syariah baru muncul beberapa tahun belakangan ini. Sehingga belum banyak alumni/sumber daya dalam bidang perbankan syariah. Namun, bank syariah menyiapkan akademi/sentra pendidikan untuk membekali seluruh karyawan. Baik dalam hal pemahaman product knowledge, akad pada bank syariah, fatwa dewan pengawas syariah, standar pelayanan dan hal-hal lain yang berkaitan dengan regulasi dan operasional bank syariah.

2) Evaluasi melalui tes sertifikasi

Perusahaan juga memberikan evaluasi pemahaman karyawan melalui tes sertifikasi sesuai dengan jenjang karyawan. Evaluasi ini dapat dijadikan penilaian dan peningkatan pengetahuan tentang perbankan syariah. Sertifikasi ini juga menjadi reward dan diharapkan dapat meningkatkan motivasi kerja karyawan pada bank syariah.

b. Produk

1) Menggalakkan gerakan \#ayo hijrah

Salah satu daya tarik bank syariah adalah tidak adanya riba bunga bank syariah. Pelayanan perbankan yang syari dan sesuai dengan tuntunan agama Islam menjadi salah satu andalan dalam memasarkan produk bank syariah. Gerakan \#ayohijrah adalah gerakan mengajak masyarakat untuk beralih dari bank konvensional ke bank syariah. Gerakan ini dimaknai tidak hanya atas dasar profit oriented namun juga falah oriented.

Melalui gerakan \#ayohijrah diharapkan dapat membuka mindset negatif masyarakat tentang bank syariah, dan mau berpindah/ berhijrah ke bank syariah. Salah satu bentuk gerakan ini dengan melakukan seminar dan workshop.

2) Melakukan kerjasama dengan instansi dengan basic islam

Upaya pengembangan selanjutnya yang dilakukan oleh bank syariah adalah dengan melakukan strategi jemput bola pada instansi dengan basic islam, misalnya pondok pesantren, sekolah, dan institusi-institusi islam. Institusi dengan basic islam memiliki visi dan misi dengan bank syariah. Secara umum, institusi dan SDMnya telah mengetahui makna akad dan urgensi menggunakan produk perbankan syariah, sehingga satu visi dengan bank syariah. Hal ini juga memudahkan bank syariah dalam mencapai target bank syariah.

c. Layanan

1) Program tabungan berhadiah

Dalam hal etika dan layanan, bank syariah melakukan upaya pengembangan melalui program tabungan berhadiah. Upaya pengembangan ini merupakan suatu program, dimana nasabah mem- 
berikan setoral awal, lalu melakukan setoran dana dalam jumlah dan jangka waktu tertentu. Nasabah akan mendapat hadiah langsung, sesuai dengan nominal dana yang disetorkan. Hadiah berbentuk TV, laptop, emas logam mulia, gadget, sepeda motor hingga mobil.

2) Melakukan strategi jemput bola

Strategi jemput bola, adalah suatu strategi pemasaran dimana pihak penjual (dalam hal ini bank syariah) datang dan menawarkan produknya kepada calon nasabah. Melalui strategi ini, calon nasabah dapat mengetahui keunggulan brand produk tersebut secara detail karena bisa bertanya langsung pada karyawan bank, tanpa perlu meluangkan waktu dan tenaga datang ke kantor bank syariah. Bagi pihak bank syariah dapat menggugah minat calon nasabah yang awalnya tidak tertarik atau belum mengetahui produk bank syariah yang ditawarkan kemudian tertarik untuk menjadi calon nasabah. Pihak bank dapat mengeksplore kemampuan marketingnya untuk mempengaruhi calon nasabah agar menjadi nasabah. Dalam hal ini bank syariah melakukan strategi jemput bola ke pondok pesantren, sekolah-sekolah islam.

\section{PENUTUP}

\section{Simpulan}

Berdasarkan temuan penelitian melalui hasil wawancara dengan informan, terungkap bahwa masalah yang dihadapi bank syariah Madiun yaitu:

\section{a. Masalah SDM}

Masalah bidang SDM meliputi motivasi kerja karyawan, Trust masyarakat pada perbankan syariah yang masih rendah, Mindset masyarakat tidak ada perbedaan bank konvensional dengan perbankan syariah.

b. Masalah Produk

Akad yang umum digunakan adalah almudharabah dan al-wadiah (titipan) Istilah dalam akad bank syariah masih baru dalam masyarakat Indonesia, begitu pula bagi masyarakat di Kabupaten Madiun. Hal ini terkadang menimbulkan permasalahan "miss persepsi" antara karyawan (Account Officer, Funding Officer dan Custumer Services) dengan nasabah tentang akad syariah dan penerapanya.

Adapun upaya pengembangan yang dilakukan untuk mengatasi masalah yang timbul adalah sebagai berikut:

a. Sumber Daya Manusia

Pengembangan karyawan melalui trainee dan sertifikasi, Evaluasi melalui tes sertifikasi

b. Produk

Upaya pengembangan melalui penggalakkan gerakan \#ayohijrah serta melakukan kerjasama dengan instansi dengan basic islam.

c. Layanan

Dalam hal pengembangan dari segi layanan konsumen, melakukan program tabungan berhadiah langsung dan strategi jemput boal ke nasabah.

\section{Saran}

Berdasarkan temuan penelitian, maka peneliti memberikan saran bagi bank syariah untuk memperbanyak sosialisasi ke masyarakat terkait akad dan produk bank syariah. Dari segi SDM bank syariah hendaknya memberikan forum peningkatan kinerja untuk meningkatkan motivasi kerja. Sedangkan dari segi pelayanan tetap menerapkan pelayanan prima yang sesuai dengan SOP bank syariah. 


\section{DAFTAR PUSTAKA}

Arshaad, Muhammad Usman., Yusoff, Mohammed Effandi., Tahir, Muhammad Sohai. (2016). Issues in Transformation from Conventional Banking to Islamic Banking. International Journal Of Econommics and Financial Issues, 6 Special Issues (S3), 220-224.

Astuti, S.P.,Wilasari,W.,\& Utami, D.E. (2012). Meningkatkan Kualitas Pelayanan Di Bank Syariah Penelitian Dengan Fuzzy Servequal dan Dimensi Carter. International Research Journal OfBusiness Studies, 2 (1).

Bank Indonesia. (2002). Cetak Biru Pengembangan Perbankan Syariah Indonesia.

Departemen Agama RI. (2007). Alquran dan Terjemahnya Special for Woman. Bandung: PT. Sygma Examedia Arkanleema.

Farizal. (2010). Pengembangan Kompetensi SDM Perbankan Syariah Melalui Corporote University. Forum Riset Perbankan Syariah II. Yogyakarta: Universitas Muhamadiyah Yogyakarta.

Ghofur, Abdul. (2017). Pengantar Ekonomi Syariah (Konsep Dasar, Paradigma, Pengembangan Ekonomi Syariah). Depok: PT. Raja Grafindo Persada.

Hadjri, Muhammad Ichsan., Perizade, Badia., Marwa, Taufiq.,Hanafi, Agustina. (2019). Islamic Human Resources Management, Organizational Commitment and Employee performance: A Case Study on Sharia Bank in South Sumatera. International Review of Management and Marketing, 9 (1), 123128.
Hakim, Lukman. (2019). Prinsip-Prinsip Lembaga Keuangan Syariah. Jakarta: Penerbit Erlangga.

https://finance.detik.com/berita-ekonomibisnis/d-2046271/indonesia-butuh200000-tenaga-ekonomi-syariah diakses 31 Januari 2020.

https://www.bankmuamalat.co.id/seputarayo-hijrah diakses 20 Februari 2020.

https://www.bps.go.id/statictable/2020/01/2 1/2082/bank-dan-kantor-bank-20142018.html diakses 31 Januari 2020.

Institut Pertanian Bogor. (2004). Potensi, Preferensi dan Perilaku Masyarakat Terhadap Bank Syariah di Wilayah Kaliamntan Selatan. Kerjasama Direktorat Perbankan Syariah-Bank Indonesia dengan Institusi Pertanian Bogor.

Kasmir. (2015). Bank dan Lembaga Keuangan Bukan Lainnya. Jakarta: PT. Raja Grafindo Persada.

Kholiq, Restu. (2019). Pengaruh Kualitas Pelayanan Terhadap Kepuasan Nasabah Bank Syariah Mandiri di Banjarmsin Kalimantan Selatan. RELEVANCE: Journal of Management and Bussiness, 2(1) 174-188.

Marimin, A.,\& Musthofa, U. A. (2018). Signifikansi Kualitas Jasa Terhadap Kepuasan Nasabah di Bank Syariah. RELEVANCE: Journal of Management and Business, 1 (2), 137-150.

Nadia, Slimene., Sonia, Makni., Jaleleddine, Ben Rejeb. (2014). Ethical Perfomance of Islamic Banks: the Case of the Tunisian Bangking "Zaytuna” Journal of Islamic Banking and Finance. Journal of Islamic Banking and Finance, 2 (1), 107-122. 
Putra, R. P., \& Herianingrum, S. (2015). Pengaruh Kualitas Pelayanan Islami Terhadap Kepuasan dan Loyalitas Nasabah Bank BRI Syariah Surabaya. Jurnal Ekonomi Syariah Teori dan Terapan, 1 (9).

Rafidah. (2017). Alternatif Solusi Atas Problematika Pembiay a n Mudharabah. Jurnal Syarikah 3 (1), $391-402$.

Rivai, Harif Amali., Lukviarman, Niki., Syafrizal., Lukman, Syukri., Andrianus, Fery., Masrizal. Identifikasi Faktor Penentu Keputusan Konsumen Dalam Memilih Jasa Perbankan: Bank Syariah vs Bank Konvensional. Kerjasama antara bank Indonesia dan Center For Banking Research (CBR)Universitas Andalas.

Rusydiana, Aam Slamet. (2016). Analisis Masalah Pengembangan Perbankan Syariah di Indonesia Aplikasi Metode Analytic Network Process. Jurnal Bisnis dan Manajemen, 6(2), $237-246$.
Sawarjuwono, Tjiptohadi., Mooduto, M.Arie. (2005). Lampu Hijau dan Kuning Untuk Bank Syariah Di Indonesia. Jurnal Bisnis Strategi Vol 4 (1).

Shidiqi, Khalifany Ash., Rachmawati, Aulifah. (2018). Determinants of Sharia Banks Efficiency in Indonesia: A Panel Data Analysis. Jurnal Ekonomi Pembangunan:Kajian Masalah Ekonomi dan Pembangunan, 19 (2),186-195.

Syauqoti, Roifatus., Ghozali, Mohammad. (2018). Analisis sistem lembaga keuangan syariah Dan lembaga keuangan konvensional. Jurnal Ekonomi dan Bisnis Islam 14 (1), 15-20.

Winarni, Endang Widi. (2018). Teori dan Praktik Penelitian Kuantitatif Kualitatif Penelitian Tindikan Kelas (PTK) Research and Development $(R \& D)$. Jakarta: Bumi Aksara.

Yusuf, burhanuddin. (2015). Human Resources Development of Sharia Banking. Al-Iqtishad Journal of Islamic of Economics Vol. VIINo.2, 241-25. 